\title{
Extreme climatic events shape arid and semiarid ecosystems
}

Milena Holmgren ${ }^{1 *}$, Paul Stapp ${ }^{2 *}$, Chris R Dickman ${ }^{3}$, Carlos Gracia $^{4}$, Sonia Graham ${ }^{5}$, Julio R Gutiérrez ${ }^{6}$, Christine Hice ${ }^{7}$, Fabián Jaksic ${ }^{8}$, Douglas A Kelt ${ }^{9}$, Mike Letnic ${ }^{10}$, Mauricio Lima ${ }^{8}$, Bernat C López ${ }^{4}$, Peter L Meserve $^{11}$, W Bryan Milstead ${ }^{12}$, Gary A Polis ${ }^{13}$, M Andrea Previtali ${ }^{11}$, Michael Richter ${ }^{14}$, Santi Sabaté ${ }^{4}$, and Francisco A Squeo ${ }^{6}$

Climatic changes associated with the El Niño Southern Oscillation (ENSO) can have a dramatic impact on terrestrial ecosystems worldwide, but especially on arid and semiarid systems, where productivity is strongly limited by precipitation. Nearly two decades of research, including both short-term experiments and long-term studies conducted on three continents, reveal that the initial, extraordinary increases in primary productivity percolate up through entire food webs, attenuating the relative importance of top-down control by predators, providing key resources that are stored to fuel future production, and altering disturbance regimes for months or years after ENSO conditions have passed. Moreover, the ecological changes associated with ENSO events have important implications for agroecosystems, ecosystem restoration, wildlife conservation, and the spread of disease. Here we present the main ideas and results of a recent symposium on the effects of ENSO in dry ecosystems, which was convened as part of the First Alexander von Humboldt International Conference on the El Niño Phenomenon and its Global Impact (Guayaquil, Ecuador, 16-20 May 2005).

Front Ecol Environ 2006; 4(2): 87-95

$E^{1}$ 1 Niño Southern Oscillation (ENSO) is fundamentally a climatic and oceanographic phenomenon, but it has profound effects on terrestrial ecosystems as well. Although the ecological effects of ENSO are becoming increasingly known from a wide range of terrestrial ecosystems (Holmgren et al. 2001; Wright 2005), their impacts have been most intensively studied in arid and semiarid systems. Because inter-annual variability in precipitation is such a strong determinant of productivity in dry ecosystems, increased ENSO rainfall (Panel 1) is crucial for plant recruitment, productivity, and diversity in these ecosystems. Several long-term studies

\section{In a nutshell:}

- El Niño Southern Oscillation (ENSO) events have a profound impact on arid and semiarid ecosystems, with important implications for agriculture, human populations, and natural resources conservation and restoration

- Although most ecological effects are mediated by increases in plant growth, changes in resources and population levels can trigger complex trophic interactions involving multiple resources, prey, and predator species

- Because ENSO effects may persist for months or even years, their consequences are best elucidated by long-term, ecosystem-scale, comparative studies

\footnotetext{
${ }^{1 *}$ Resource Ecology Group, Wageningen University, Bornsesteeg 69, Building 119, 6708 PD Wageningen, The Netherlands (milena. holmgren@wur.nl); ${ }^{2 *}$ Department of Biological Science, California State University, PO Box 6850, Fullerton, CA 92834-6850, USA (pstapp@fullerton.edu); ${ }^{3}$ Institute of Wildlife Research, University of Sydney, NSW 2006, Australia; (continued on p 95)
}

show that this pulse in primary productivity causes a subsequent increase in herbivores, followed by an increase in carnivores, with consequent changes in ecosystem structure and functioning that can be quite complex and pervasive. We begin by discussing the effects on plant communities, then move to studies of populations of higher-level consumers and entire food webs. Where appropriate, we discuss the implications of ENSO events for land-use practices, natural resource management, and humans. We conclude with a brief synthesis, including suggestions for additional work needed in this important area.

\section{Plant responses}

\section{Production of herbaceous plants and seed banks}

Herbaceous plants in arid and semiarid ecosystems respond very rapidly to pulses of precipitation by germinating, growing, and producing large quantities of seed (Figure 1). For instance, Julio Gutiérrez and colleagues have been studying the arid scrub communities in northcentral Chile since 1989, and have described changes in ephemeral plant cover, from $11-16 \%$ pre-El Niño 1989-90 to 54-80\% during El Niño 1991-92 and back to 13-21\% post-El Niño 1993-94 (Gutiérrez et al. 1997). Comparable responses have been described for the Galápagos Islands (Hamann 1985), islands in the Gulf of California (Polis et al. 1997), and the Atacama Desert in Chile (Vidiella et al. 1999) and Peru (eg Block and Richter 2000).

Plant species composition also changes in El Niño 

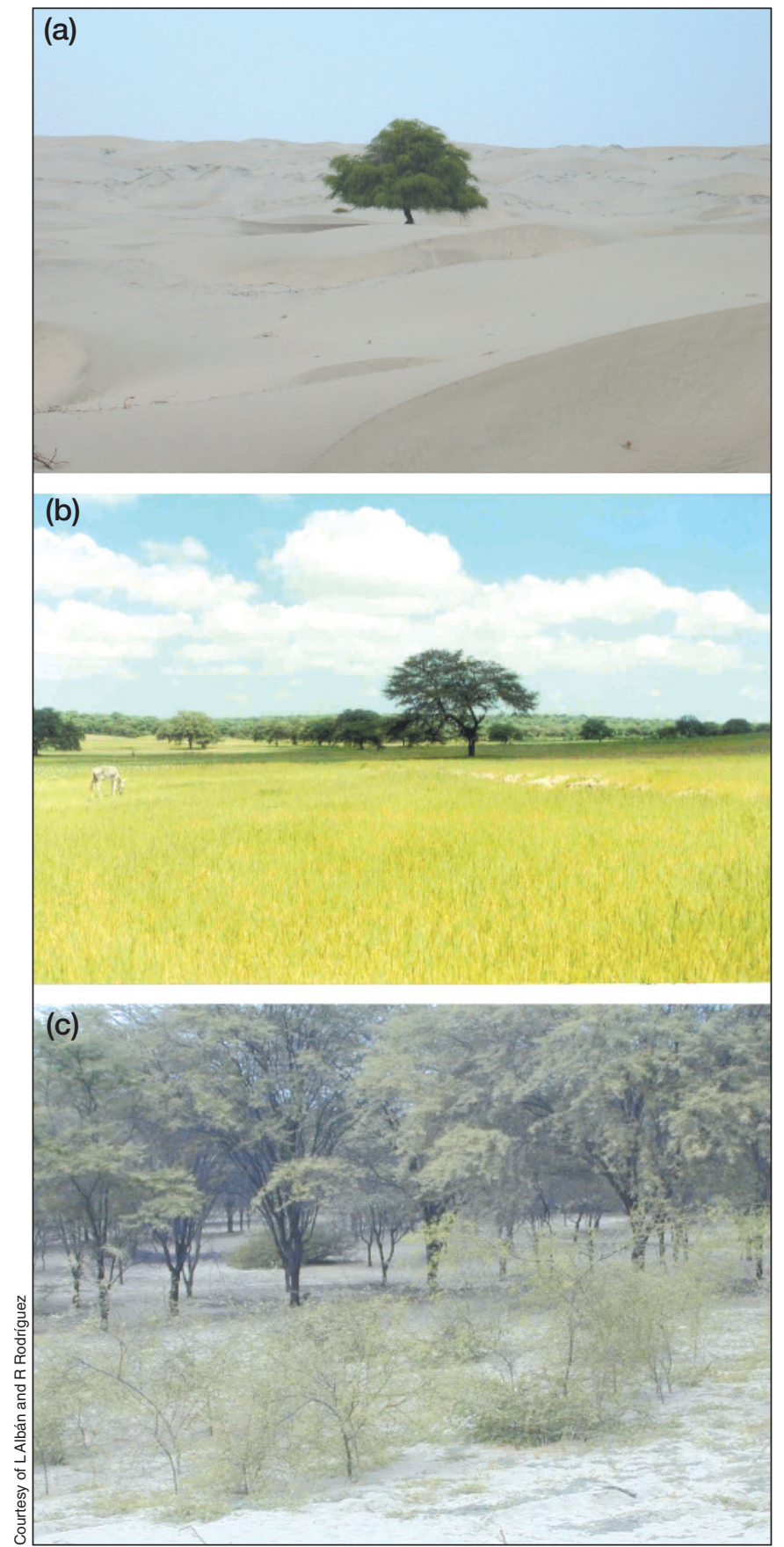

Figure 1. Effects of El Niño rainfall on the forests of northwest Peru. The normally sandy landscapes with scattered Prosopis pallida trees (a) become covered by pastures $(b)$ and by new recruited trees $(c)$.

years. Some species that are absent or rare during non-El Niño years become dominant during the rainy events. Annual species that respond strongly to infrequent rainfall pulses, such as those ocurring in El Niño years, appear to be able to survive in the system, buffering the absence of sufficient water during dry years, by producing large seed reserves during rainy pulses. As a consequence, there is very little correlation between seed bank composition and the species found growing during dry years (Gutiérrez et al. 2000). It is interesting to note that the responses of ephemeral plants to rainfall pulses seem to be related to the rainfall regime in previous years. For instance, at one experimental site in Chile, the cover of ephemeral plants in 1991 (223 $\mathrm{mm}$ rainfall) peaked at $80 \%$ and then decreased to $54 \%$ in 1992 , despite this also being a comparably wet year $(229 \mathrm{~mm})$. These observations suggest that other factors, such as nutrients, become limiting after the first rainy pulse (Gutiérrez et al. 1997).

\section{Effects in dry forests and shrublands}

ENSO events represent large interannual rainfall pulses of long duration. These resource pulses can trigger responses in many types of organisms, including not only those species that are able to use short pulses of increased superficial soil water, but also deeper-rooted shrubs and trees (Schwinning and Sala 2004; see also additional papers in the same volume of Oecologia). A major consequence of rainy conditions associated with ENSO is the regeneration of woody vegetation (Figure 1). Examples include increased shrub cover in the Chihuahuan desert (Brown et al. 1997) and the successful establishment of cactus seedlings in the Sonoran desert (Bowers 1997) during rainy El Niño events, as well as the regeneration of mulga, Eucalyptus, and conifer woodlands in semiarid Australia during wet La Niña episodes (Austin and Williams 1988).

In northwest Peru, spectacular natural regeneration of several tree species has been observed during the very strong ENSO events of 1982-83 and 1997-98. Bernat C López and colleagues studied growth and recruitment in one of the most dominant native tree species of the Peruvian dry forests (Prosopis pallida) and compared this with Prosopis chilensis in north-central Chile. They found that in northwest Peru, mean annual growth rate (López et al. 2005) and recruitment of new $P$ pallida trees were positively correlated with annual rainfall, and were almost twice as high during ENSO years than during nonENSO years. In contrast, neither recruitment nor growth rate of $P$ chilensis in northern Chile was significantly correlated to rainfall and ENSO conditions. These results make sense in light of the differences in ENSO-related precipitation between the two regions; precipitation in northwest Peru increases enormously during ENSO years (up to 25 times higher than during non-ENSO years) but only moderately (1.6 times) in north-central Chile.

\section{Implications for land-use management and restoration}

Although one might imagine that an ecosystem basically tracks the fluctuations in environmental conditions, a fundamentally different trajectory may be seen in ecosystems that have alternative stable states. Semiarid ecosystems can have alternative vegetation states (eg dry forests and shrublands vs degraded savannas and barren soil) depending on grazing and water availability (eg Rietkerk 
and van de Koppel 1997). This may have considerable implications for their response to variability in climate such as ENSO events and global climate change (Scheffer et al. 2005), which may result in catastrophic regime shifts (Scheffer and Carpenter 2003). Holmgren and Scheffer (2001) hypothesized that ENSO episodes of increased rainfall can be used together with grazing control to enhance plant establishment and produce permanent shifts in ecosystem state (Figure 2). Together with colleagues, Milena Holmgren has been searching for evidence of this in the semiarid ecosystems of north-central Chile and northwest Peru, using tree-ring studies in natural populations and field experiments with seedlings. They found that rainy El Niño episodes can indeed trigger forest regeneration, but that, as discussed earlier, large regional differences exist. Experiments revealed that this is due not only to the smaller ENSO signal in Chile, but also to a much greater mortality caused by herbivores. The huge impact of species in Chile seems to be the combined result of slower plant growth and greater pressure from exotic species (especially European rabbits and hares). These results suggest that ENSO events may be used as "windows of opportunity" to trigger forest recovery if herbivores are controlled at the right moment. Clearly, the successful use of ENSO events in restoration programs will depend on a combination of climatic, ecological, and social conditions (Scheffer et al. 2002). Currently, El Niño forecasts are being used for the implementation of reforestation programs in northwest Peru, although with no systematic control of herbivores and with varying degrees of success (eg Vilela 2002).

While studies conducted in the Western Hemisphere highlight the importance of boosts in primary productivity associated with ENSO-related pulses in rainfall, research in Australia also demonstrates the implications of ENSO-related drying events for restoration and reforestation efforts. Numerous tree species in Australia have developed drought tolerance, but high seedling death rates due to water and heat stress are common for both natural populations and planted seedlings. Indeed, while recruitment of many plant species fails during dry El Niño conditions, rainy La Niña years stimulate primary productivity and woodland regeneration (Austin and Williams 1988). Research is currently being undertaken to investigate how ENSO-related dry periods and La Niña-related wet periods affect native tree establishment and to assess how seasonal climate forecasting may be used to both reduce the risk of unsuccessful establishment and predict

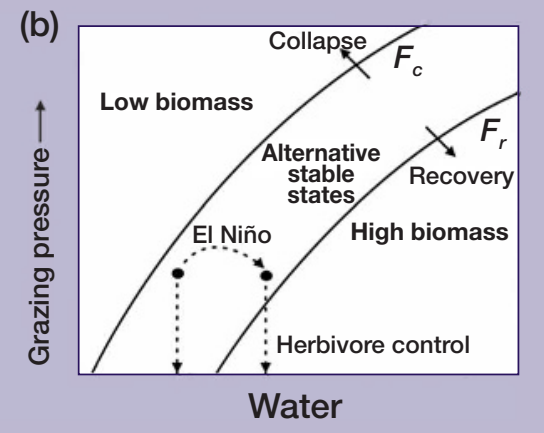

Figure 2. (a) Equilibrium biomass of vegetation in semi-arid regions as a function of grazing pressure. The inflection points (dots) of the curve are fold bifurcations that mark critical biomass removal rates. At grazing pressures higher than $F_{c}$ the vegetation can condition is the only stable state. At intermediate grazing pressure (between $F_{c}$ and $F_{r}$ ), system. Here, the dashed middle section of the sigmoidal curve represents an unstable (b) Critical thresholds of biomass removal as a function of water availability. Under wetter conditions, equilibrium biomass and the critical grazing pressure for collapse $\left(F_{c}\right)$ or recovery $\left(F_{r}\right)$ are higher. A certain reduction of biomass removal rate (eg herbivory indicated by the vertical arrows may be sufficient to induce woodland recovery in a wet ("El Niño") year, but not in a dry year. (Reproduced courtesy of Springer Science and Business Media; Holmgren and Scheffer 2001.)

the occurrence of conditions that are conducive to successful establishment (Howden et al. 2004).

The primary productivity boost described previously and its potential application in ecosystem restoration could be overshadowed by fires and overgrazing. Although plant regeneration improves when herbivore pressure declines (Holmgren and Scheffer 2001), overgrazing during the subsequent dry years is likely to become a problem, because both native herbivores and livestock increase numerically during the rainy pulse. In addition, abundant dry grasses serve as high fuel loads, facilitating the initiation and spread of large fires. Clear links between ENSO and fire are found in arid lands in Australia (Skidmore 1987), northwest Peru (Block and Richter 2000; Richter and Ise 2005), and the southwestern US (Westerling et al. 2003). This is reflected in the striking similarity between fire histories in the southwestern US and northern Patagonia over the past century, with major fires happening during dry La Niña events (Kitzberger et al. 2001). The frequency and intensity of wildfires in tropical systems are also influenced by ENSO and can release large amounts of carbon to the atmosphere (Page et al. 2002; Cochrane 2003).

\section{Consumer population and food-web responses}

Notwithstanding the ground-breaking work by Peter and Rosemary Grant on the ecology and evolution of Darwin's finches on the Galápagos Islands (Grant and Grant 1989; Grant et al. 2000), some of the best evidence for the ecological effects of ENSO events on consumer 
Panel 1. The ENSO cycle and its weather effects (from McPhaden 2004)

The El Niño Southern Oscillation (ENSO) cycle is the most prominent source of interannual climatic variation on our planet. This oscillation has two opposite phases, known as El Niño and La Niña. Normally, trade winds along the equator blow from east to west, piling warm, superficial seawater in the western Pacific (Figure 3b). As a consequence, cold, deep water is pushed deeper in the west and elevated in the east, which facilitates the upwelling of cold water off the western coast of South America. As the trade winds blow, they collect heat and moisture from the ocean. The warm humid air becomes less dense and rises over the warm western Pacific waters, a region with low atmospheric pressure. Deep convection produces heavy precipitation. The air then returns eastwards and sinks over the cooler waters of the eastern Pacific, generating a high-pressure region.

El Niño begins when the trade winds weaken as atmospheric pressure rises in the western Pacific and falls in the eastern Pacific. Weakened trade winds allow water from the warm seawater pool in the western Pacific to move eastward, reducing coastal upwelling of deep cold water (Figure $3 c$ ). As surface sea temperature warms up in the eastern Pacific, convective cloudiness and rainfall migrate eastwards. This process further weakens the trade winds, shifting the rain zone towards the central and eastern Pacific. As a result, drought conditions affect large portions of Australia, Indonesia, and the Philippines, while torrential rains often occur in the island states of the central Pacific and along the west coast of South America. This shift in the rainfall convective zone also leads to changes in atmospheric circulation (known as teleconnections) that propagate the influence of EI Niño worldwide.As a consequence, during an El Niño episode, rainfall dramatically increases in certain areas of the world, while severe droughts occur in other regions (Figure 4a).

The El Niño phase lasts approximately one year before the climatic conditions reverse. The next phase, known as La Niña, is characterized by stronger than normal trade winds and a shift in heavy rainfall to the far western tropical Pacific (Figure 3a). La Niña produces roughly the opposite climate patterns from those seen during an El Niño episode (Figure 4b). The oscillation between El Niño and La Niña is irregular, but typically occurs once every 3-6 years (Allan et al. 1996; McPhaden 2004).

The strength of the ENSO effects varies both spatially and temporally. For example, during an El Niño year, rainfall may double in north-central Chile, while it can be more than 25 times higher than normal in northern Peru. The strength, duration, and frequency of ENSO events seem to be affected by other climatic oscillations, such as the Pacific Decadal Oscillation (PDO).

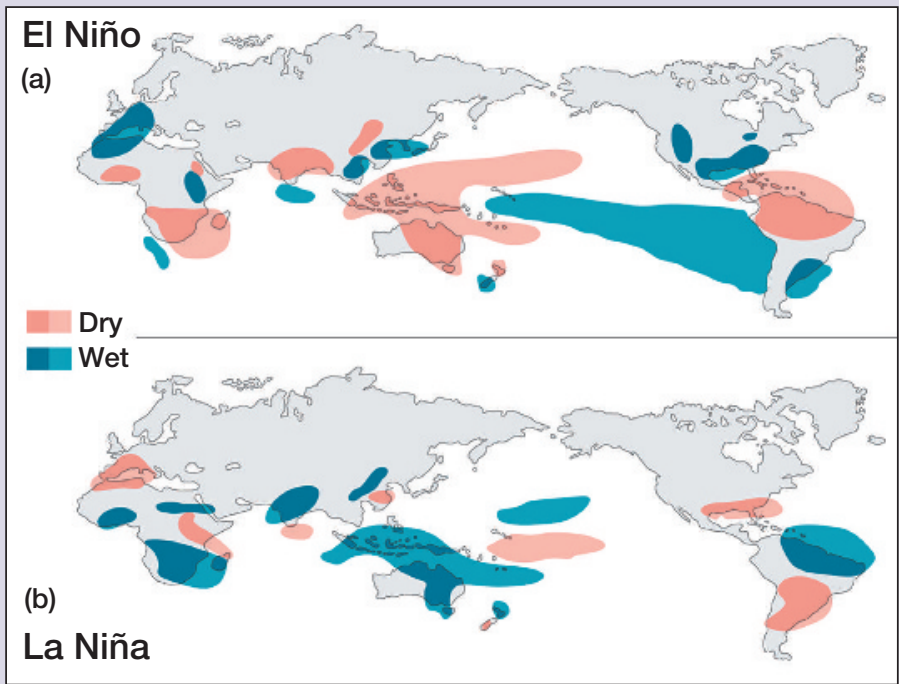

Figure 4. Regions showing increased precipitation (blue) and drier conditions (orange) during (a) El Niño and (b) La Niña phases. (From Allan et al. 1996.) populations has come from studies involving small mammals, which are important components of arid and semiarid ecosystems. In addition, because many small mammals are commensal, or interact with humans directly or indirectly, population irruptions during ENSO events are often viewed as pest outbreaks, which may lead to increased agricultural damage or a higher risk of zoonotic diseases such as hantavirus (Hjelle and Glass 2000) and plague (Stapp et al. 2004).

\section{Population responses of small mammals and their predators}

ENSO events in semiarid Chile result in predictable increases in rainfall, which trigger flushes in vegetation and the associated size of the seed bank, especially by ephemerals (Jaksic 2001). In turn, with delays of 6-12 months, small mammal numbers increase in response to primary productivity, usually reaching irruption levels of 100 individuals $\mathrm{ha}^{-1}$ (Jaksic and Lima 2003). Mauricio Lima and colleagues conducted detailed time-series analyses to evaluate the relative importance of direct (eg survival and reproduction) and indirect effects (eg through a limiting resource) of climate on rodent abundance in semiarid Chile (Lima et al. 1999, 2002). Their findings indicate that fluctuations in rodent demographic rates are mainly the result of indirect effects of rainfall, implying that these small rodent populations are strongly food-limited and that rainfall represents a proxy for food availability. Food limitation and intraspecific competition, therefore, are dominant forces influencing the dynamics of these rodent populations.

Populations of local predators track fluctuations in rodent prey (Jaksic et al. 1992); these responses are complex, however, because different predators consume different prey and 
because predator numbers are limited by both density-dependent and interspecific interactions (Lima et al. 2002). In Auco, north-central Chile, Fabián Jaksic and collaborators have been able to detect increases in mouse numbers following precipitation associated with four ENSO events (1987, 1991, 1997, and 2002) over an 18-year period. Associated with these mouse irruptions, carnivorous mammals and birds of prey display a variety of responses at all levels of organization.

At the individual level, for instance, burrowing owls shift their consumption of prey over time, depending on the relative abundance of prey. Essentially, burrowing owls increase the consumption of irrupting mammals, shifting away from less energetically rewarding prey such as arthropods (see also Silva et al. 1995). At the pop-

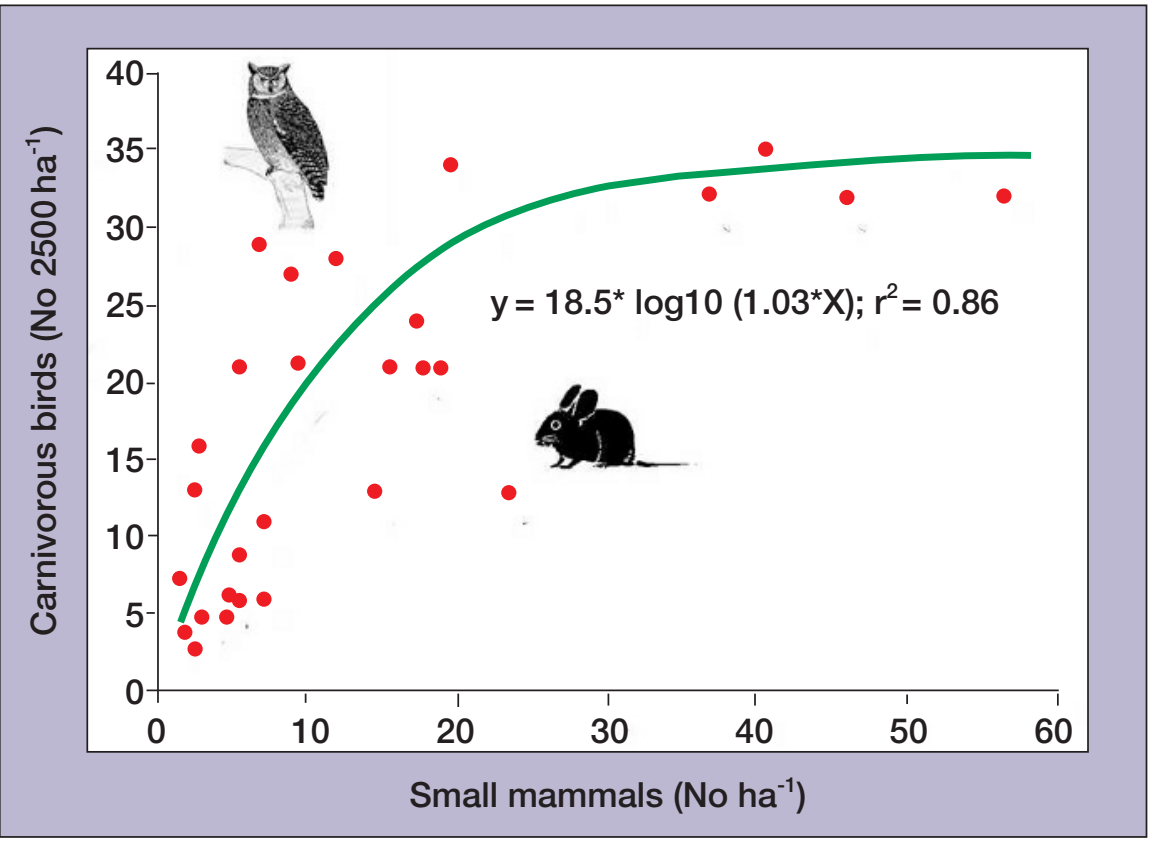

Figure 5. Numerical response of carnivorous birds to the abundance of small rodents in north-central Chile.

\section{ulation level, Jaksic and collaborators}

have identified a numerical response, with carnivorous birds displaying population fluctuations to reflect mammalian prey changes, essentially tracking their temporal course of abundance (Figure 5; Jaksic et al. 1992). Nevertheless, this numerical response is not perfect and the curve of predator versus prey numbers saturates quickly, which may explain why carnivorous birds are not able to control their mammalian prey.

Finally, at the community level, the predator assemblage as a whole shows important rearrangements of richness, composition, and structure. The most prevalent guild response is for predators to form looser guilds, with less diet similarity, during ENSO events. This occurs because during ENSO years there is greater abundance and a broader variety of available prey, so that predators can diverge in diet. During La Niña years, on the other hand, with reduced abundance and less variety of prey, predators must converge on the few prey available, thus increasing their diet similarity (Jaksic et al. 1993). Top predators in semiarid ecosystems may be considered as periodically bouncing between times of plenty (El Niño) and lean times (La Niña), in terms of their prey.

\section{Complex interactions between competition and predation}

In order to understand the effects of rainfall variability on the whole food-web structure, since 1989 Peter Meserve and his collaborators have been conducting a large-scale, experimental study of small mammals in a semiarid thorn scrub community in north-central Chile (mean annual rainfall $=143 \mathrm{~mm}$ ). This project has spanned three highrainfall episodes usually associated with the warm phase of ENSO. Though ranging in duration (1-3 years) and magni- tude $(229-356 \mathrm{~mm})$, each episode triggered strong responses in small mammal numbers, apparently in response to increasing food availability (Figure 6; Meserve et al. 2001).

Individual species, however, showed variations in response time and magnitude of population increases. For instance, some species increase rapidly in response to a rainy pulse and reach about the same maximum numbers, regardless of the duration of rainfall episodes or the annual amount (eg Phyllotis darwini and Akodon olivaceus). Others show a longer delay in response time with increased precipitation and reach higher abundance levels during more prolonged rainfall episodes (eg Octodon degus). Following the rainy pulse, some species crash numerically (eg A olivaceus), while others maintain oscillations (though smaller) in normal to dry years ( $P$ darwini). These changes seem to be related to diet (eg granivore vs herbivore) and to reproductive rate (Meserve et al. 2001).

Results from factorial experiments to exclude most vertebrate predators (ie foxes, owls, raptors) and the largest putative competitor $(\mathrm{O}$ degus $)$ also varied between species. Although competition seemed weak (Meserve et al. 1999, 2003), it appeared that the relative importance of interspecific interactions, such as predation and competition, can become stronger during dry periods. These experiments also revealed unexpected facilitative interactions among these rodents. For instance, the presence of the larger $O$ degus apparently has an indirect positive effect on $P$ darwini, by modifying habitat and creating more suitable conditions, ie opening the vegetation canopy and providing burrows. Thus, while many patterns in the structure of this small mammal assemblage may be explained by extrinsic factors such as high variability in rainfall leading to changes in resource availability, the role of interspecific interactions 


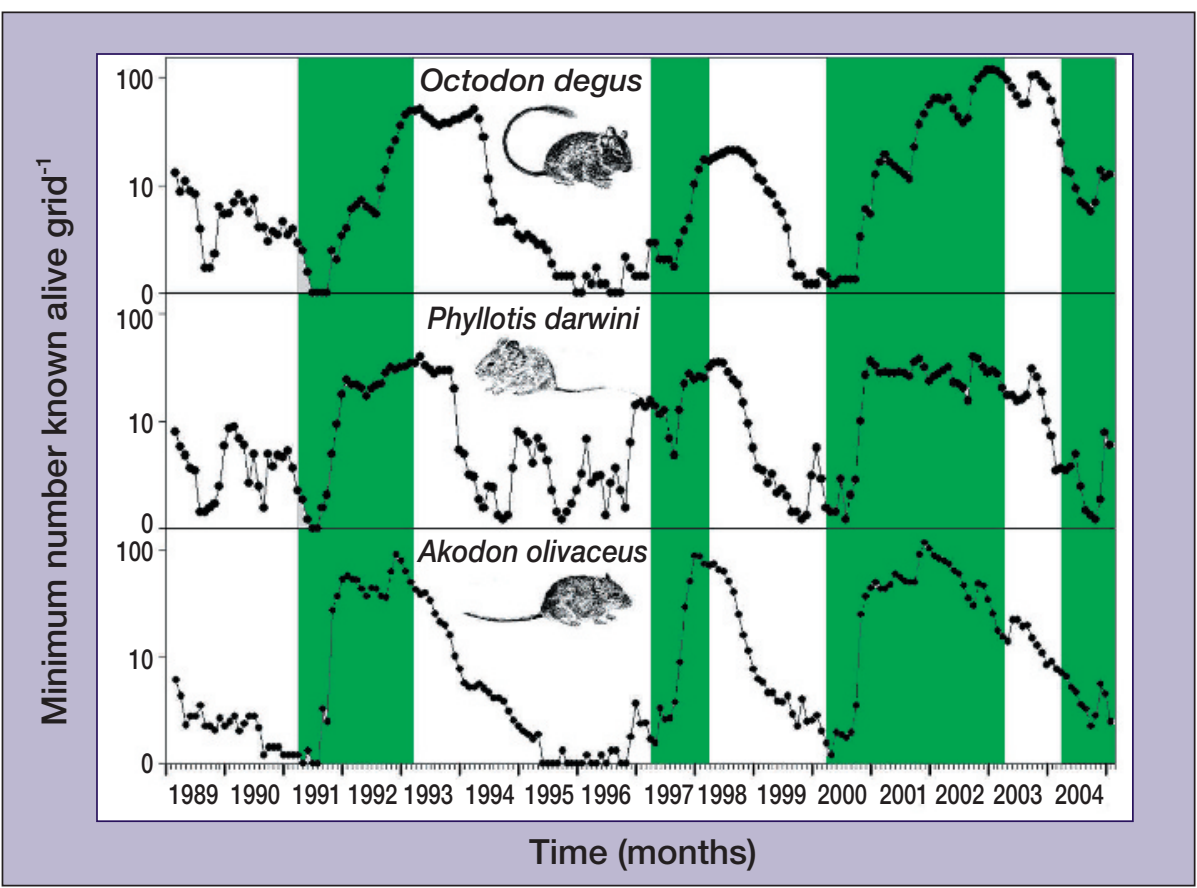

Figure 6. Fluctuations in the abundance of small mammals in response to changes in plant productivity driven by rainfall variability in semiarid north-central Chile. The green background indicates an unusually high rainfall period due to the occurrence of an El Niño event or to local climatic factors.

such as predation and competition cannot be discounted. These complex relationships could not have been detected without long-term experimental studies.

\section{Responses of Australian mammals to La Niña and wildfires}

In Australia, the El Niño and La Niña phases of ENSO are associated with drought and floods, respectively. The pulse of primary productivity that occurs during La Niña is a fundamental and periodic process that structures terrestrial ecosystems throughout Australia. For example, La Niña rains provide opportunities for the successful recruitment of annual herbs, perennial shrubs and trees, and successful breeding by waterfowl (Nicholls 1991; Kingsford et al. 1999; Figure 7).

As in South America, this pulse of plant growth results in widespread irruption of rodents (Letnic et al. 2005), followed in turn by an increase in the populations of predators, including domestic cats (Felis catus) and red foxes (Vulpes vulpes). These introduced species have been implicated in the extinction or endangerment of 26 species of native mammals throughout arid Australia. During the periods of high predator abundance that follow La Niña events, trophic pathways are temporarily reversed, as predation, competition, and disease increase in importance as factors limiting rodent populations (Letnic et al. 2004, 2005).

During droughts associated with the El Niño phase, mammal populations crash (Dickman et al. 1999, 2001) and overgrazing by livestock, kangaroos, and feral animals can lead to massive soil erosion (Ludwig et al. 1997). These erosion events can produce dysfunctional landscapes that have a diminished ability to retain soil nutrients and moisture, thus limiting potential growth responses to future rainfall events.

Once dried, the plentiful vegetation produced during La Niña events provides ample fuel for massive wildfire events in arid Australia (Figure 7). Such events were recorded in 1916-1918, 1951, 1974-75, and 2001-02, and encompassed millions of square kilometers (Letnic et al. 2005). These catastrophic wildfires have devastating impacts on native ecosystems and severe consequences for human communities (Skidmore 1987). Because periods of top-down trophic regulation and wildfires coincide about one year after La Niña events, these high rainfall periods should be regarded as critical for wildlife conservation in arid Australia, rather than as "boom times", as has traditionally been the case.

The ecology of terrestrial ecosystems in Australia is inextricably linked to ENSO. A major challenge for sustainable management of natural resources and biodiversity in this country is to incorporate climatic forecasting into adaptive management strategies that can respond to ENSO-driven variability in rainfall.

\section{ENSO effects on marine inputs and terrestrial food webs on desert islands}

The dynamics of coastal arid ecosystems are largely driven by low, variable primary productivity and inputs from the adjacent ocean. On islands in the Gulf of California, inputs of nutrients and energy from a very productive marine system act as spatial trophic subsidies, contributing to high consumer densities in typical dry years. However, episodic ENSO events bring rainfall that stimulates plant productivity, replenishes detritus and seed banks, and provides resources for insular consumers that may remain in the system after dry conditions resume (ie as temporal trophic subsidies). A decade of research led by Gary Polis and his colleagues has focused on interactions between marine inputs and pulsed ENSO resources as determinants of primary and secondary production and trophic interactions on small, rocky islands off Baja California (Polis et al. 1997; Stapp et al. 1999; Sánchez Piñero and Polis 2000; Stapp and Polis 2003). A few of these islands host nesting colonies of seabirds which provide food, in the form of carrion (ie remains of dead fishes, crabs, etc), for arthropod scavengers. Other islands are used by seabirds only for roosting and are influenced indirectly by the addition of guano, which adds 


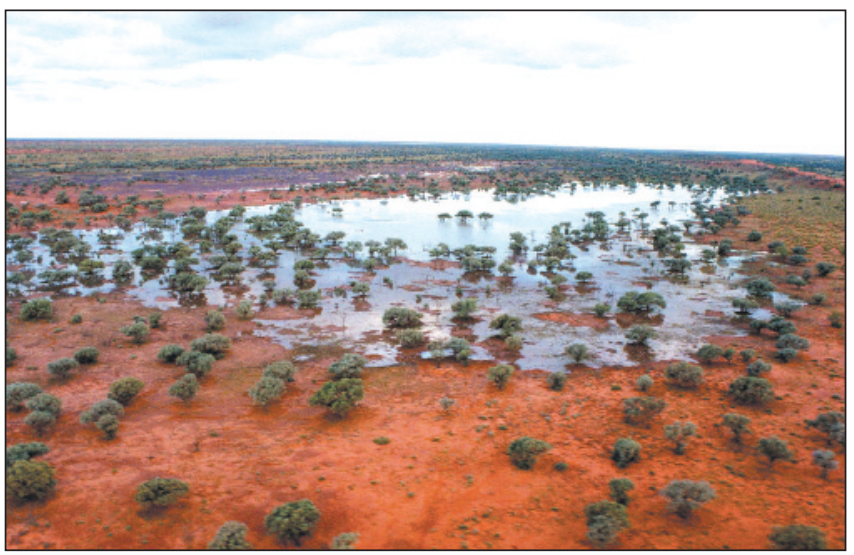

Figure 7. ENSO-related impacts in the Simpson Desert, central Australia. (a) Craven's Peak station in the northeastern part of the desert following flood rains associated with the La Niña phase of ENSO in 1999-2000. (b) The same area following a wildfire that burnt $>10000 \mathrm{~km}^{2}$ of the desert in the summer of 2001-2002. The fire, ignited by lightning strikes,

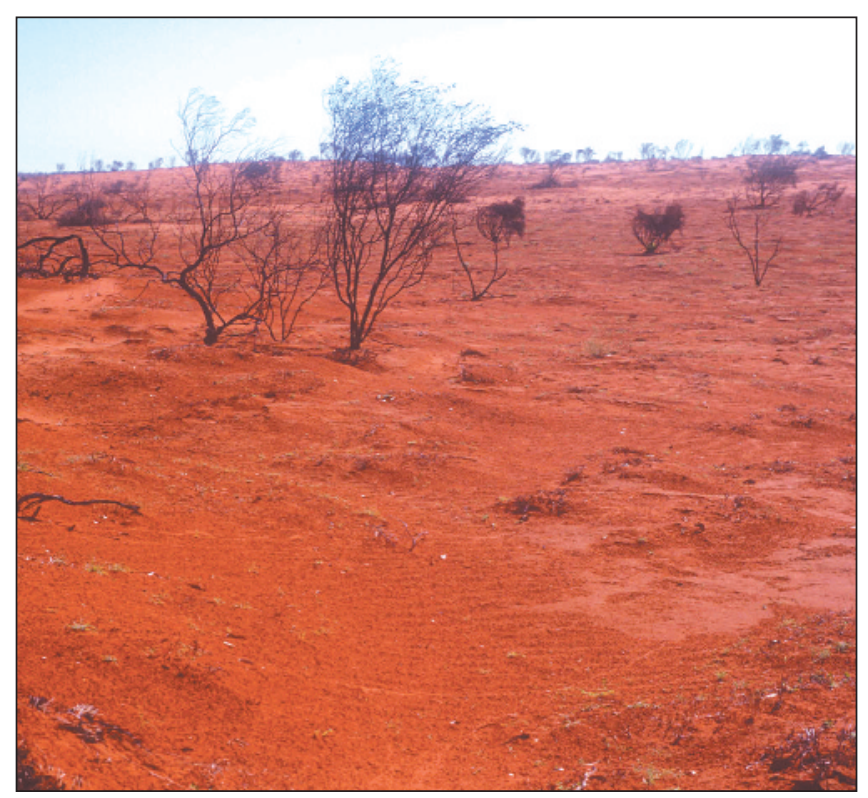
was exacerbated by a heavy fuel load of dry vegetation resulting from the earlier La Niña rains. Fires of this magnitude have occurred four times over the past century, and have followed flood rains on each occasion.

nutrients to soil that can be used by plants when water is available. There are striking differences in the ecology of these two types of islands. Polis et al.'s research coincided with three ENSO events (1991-92, 1994-95, 1997-98) in the region, during which winter precipitation $(142 \mathrm{~mm})$ was five times higher than in the intervening dry years $(28 \mathrm{~mm})$. Peaks in plant cover, particularly annuals, were associated with these wet years, increasing plant cover approximately threefold, especially on islands used by seabirds. As a result, flying insects and their primary predators, web spiders, also peaked in abundance in those years, although the increases were most pronounced on seabird islands. This indicates more bottom-up control than was suggested in previous analyses that pooled seabird and nonbird islands (Polis et al. 1997). Omnivorous rodents (Peromyscus spp) also increased fourfold during the 1997-98 El Niño conditions, but populations crashed the following year. The numerical response of these rodents contrasted with that of granivorous rodents (Chaetodipus spp), which experienced only a modest increase (1.6 times), but whose populations remained much more stable once dry conditions resumed (Stapp and Polis 2003). These results suggest very different responses to ENSO-related pulses, in which some species (eg omnivorous rodents, web spiders) show strong, immediate population increases, whereas others (eg granivores, scavenging arthropods) may display more muted or extended responses, mediated by interactions with other species or the availability of marine resources (Sánchez Piñero and Polis 2000; Stapp and Polis 2003). Results from stable carbon and nitrogen isotope analyses have confirmed the overwhelming importance of marine resources for many consumers in dry years, while marine and insular systems remain largely distinct during wet years, except for the profound, indirect effects of seabird guano on terrestrial productivity (Stapp et al. 1999).
This insular system is unique in its tight linkage between the marine and terrestrial components. Additional work is needed on the persistence of pulsed resources (eg seed/litter banks, consumer tissue), and on the potential impacts of ENSO-related changes in marine productivity on inputs to insular food webs. In addition to reinforcing the notion that episodic, ENSO-driven rainfall events are critical factors in the ecology of arid and semiarid systems, this work demonstrates the interdependence of ocean and terrestrial systems and the key role of seabirds in some insular food webs. This, in turn, underscores the importance of a healthy marine environment and the protection of seabirds to the conservation of insular ecosystems.

\section{Interactions between ENSO and zoonotic disease}

As in other arid regions, rodent populations in the southwestern US are markedly affected by ENSO-related rainfall (Brown and Ernest 2002). Because some of these species can transmit diseases to humans, understanding their population dynamics and behavior has important health implications. Since 1994, researchers at the University of New Mexico and Centers for Disease Control and Prevention (CDC) have been studying the effects of climate variability on rodent populations and hantavirus produced by the Sin Nombre virus (SNV). SNV was first discovered in New Mexico following an outbreak of hantavirus pulmonary syndrome after the 1992-93 ENSO; this was eventually traced back to an increase in numbers of deer mice (Peromyscus maniculatus) and other rodents in the family Muridae. Clearly, the numerical response of deer mice to ENSO events has important consequences for the ecology of hantavirus. Deer mice can take rapid advantage of increased food resources during ENSO events because they reproduce several times per year and have large num- 
bers of offspring. Other species, including rodents such as kangaroo rats (Dipodomys spp; Heteromyidae) do not transmit the disease and apparently do not respond as strongly to ENSO pulses. Kangaroo rats typically have only one litter per year, making them less able to increase in abundance in response to improved food availability. Moreover, their territorial behavior often makes space, not food resources, the limiting factor. Current research aims to identify, through satellite imagery, the characteristics of sites that act as refugia for Peromyscus populations during dry years, thereby serving as sources for high rodent numbers in outbreak years that are associated with ENSO events.

\section{- Synthesis and conclusions}

Two decades of research using a combination of long-term observations and experimental field studies have demonstrated profound and persistent impacts of ENSO-related rainfall variability on the dynamics of arid and semiarid ecosystems. Some general patterns were apparent in the three continents studied; however, there are regional differences in the relative importance of ENSO events, as well as in the magnitude of its effects. The basic pattern is that a rainy episode triggers a pulse in plant growth, leading to an increase in herbivores, and later in carnivores. In subsequent dry periods, top-down effects can become strong and food again becomes a limiting factor in these elevated populations. Within trophic levels, species clearly differ in their response to ENSO events, often in surprising ways that may be mediated by interactions with other species. Many of the studies described above focus on biotic effects, which may be important at local or relatively short temporal scales. Additional time-series data, collected from across a range of representative sites, are clearly needed to scale-up these local processes to relevant regional scales, and to permit generalizations about the ecological importance of ENSO and other broad-scale external factors.

Importantly, ENSO-related changes in terrestrial ecosystems can have substantial effects on human communities and land use. Accumulated dry plant material, for example, can fuel wildfires after the rainy period is over. In contrast, forest regeneration and expansion could be a longlasting result of a wet ENSO event, because trees and shrubs become relatively less sensitive to drought and herbivory once they reach a certain critical size. Although ENSO conditions can pose substantial challenges in wildlife conservation and the management of vectors and hosts of human diseases, such events also represent opportunities for novel approaches in restoration and natural resources management. Future research should focus on how seasonal and long-range ENSO forecasting could be applied to adaptive management of these issues (eg current models used to predict likelihood and severity of fire season by ecologists and fire meteorologists in the US; www.nifc.gov/nicc/predictive/predictive.htm). The climatic extremes associated with ENSO events, especially in arid and semiarid systems, also provide prime opportunities for natural experiments to test fundamental questions about ecosystem stability and the direct and indirect consequences of pulsed resources in food webs.

\section{Acknowledgments}

We gratefully acknowledge the efforts of the technicians, students, and volunteers who contributed to the success of these projects, as well as the governmental agencies that facilitated our research. These results were collected with generous, long-term support from the EU-INCO project (M Holmgren and colleagues; www.biouls.cl/enso/), US National Science Foundation (P Stapp, P Meserve and colleagues), FONDECYT (Chile; J Gutiérrez and colleagues), Australian Research Council (C Dickman, M Letnic and colleagues), and US Centers for Disease Control and Prevention (C Hice). S Graham thanks the Land and Water Australia's Managing Climate Variability Program for their ongoing support. JR Gutiérrez and FA Squeo thank the BBVA Foundation Prize in Research and Conservation Biology (Spain) for their support. We are particularly grateful to MJ McPhaden (NOAA/PMEL/TAO Project Office) for generously helping us prepare Panel 1.

\section{References}

Allan R, Lindesay J, and Parker D. 1996. El Niño Southern Oscillation and climatic variability. Collingwood, Australia: CSIRO. www.publish.csiro.au/pid/184.htm.

Austin MP and Williams O. 1988. Influence of climate and community composition on the population demography of pasture species in semi-arid Australia. Vegetatio 77: 43-49.

Block MA and Richter M. 2000. Impacts of heavy rainfalls in El Niño $1997 / 98$ on the vegetation of Sechura Desert in Northern Peru. Phytocoenologia 30: 491-517.

Bowers JE. 1997. Demographic patterns of Ferocactus cylindraceus in relation to substrate age and grazing history. Plant Ecol 133: $37-48$.

Brown JH and Ernest SKM. 2002. Rain and rodents: complex dynamics in desert communities. BioScience 52: 979-87.

Brown JH, Valone TJ, and Curtin CG. 1997. Reorganization of an arid ecosystem in response to recent climate change. P Natl Acad Sci USA 94: 9729-33.

Cochrane MA. 2003. Fire science for rainforests. Nature 421: 913-19.

Dickman CR, Mahon PS, Masters P, and Gibson DF. 1999. Longterm dynamics of rodent populations in arid Australia: the influence of rainfall. Wildlife Res 26: 389-403.

Dickman CR, Haythornthwaite AS, McNaught GH, et al. 2001. Population dynamics of three species of dasyurid marsupials in arid central Australia: a 10-year study. Wildlife Res 28: 493-506.

Grant PR and Grant BR. 1989. Evolutionary dynamics of a natural population: the large cactus finch of the Galápagos. Chicago, IL: University of Chicago Press.

Grant PR, Grant BR, Keller LF, and Petren K. 2000. Effects of El Niño events on Darwin's finch productivity. Ecology 81: 2442-57.

Gutiérrez JR, Arancio G, and Jaksic FM. 2000.Variation in vegetation and seed bank in a Chilean semi-arid community affected by ENSO 1997. J Veg Sci 11: 641-48.

Gutiérrez JR, Meserve PL, Herrera S, et al. 1997. Effects of small mammals and vertebrate predators on vegetation in the Chilean semiarid zone. Oecologia 109: 398-406.

Hamman O. 1985. The El Niño influence on the Galápagos vegetation. In: Robinson G and Del Pino EM (Eds). El Niño en las Islas 
Galápagos: el evento de 1982-1983. Quito, Ecuador: Fundación Charles Darwin para las Islas Galápagos.

Hjelle B and Glass GE. 2000. Outbreak of hantavirus infection in the Four Corners region of the United States in the wake of the 1997-1998 El Niño-Southern Oscillation. J Infect Dis 181: 1569-73.

Holmgren M and Scheffer M. 2001. El Niño as a window of opportunity for the restoration of degraded arid ecosystems. Ecosystems 4: 151-59.

Holmgren M, Scheffer M, Ezcurra E, et al. 2001. El Niño effects on the dynamics of terrestrial ecosystems. Trends Ecol Evol 16: 89-94.

Howden SM, Crimp S, Carter J, et al. 2004. Enhancing natural resource management by incorporating climate variability into tree establishment decisions - final report for Land and Water Australia. Collingwood, Australia: CSIRO.

Jaksic FM. 2001. Ecological effects of El Niño in terrestrial ecosystems of western South America. Ecography 24: 241-50.

Jaksic FM and Lima M. 2003. Myths and facts on ratadas: bamboo blooms, rainfall peaks and rodent outbreaks in South America. Austral Ecol 28: 237-51.

Jaksic FM, Jiménez JE, Castro SA, and Feinsinger P. 1992. Numerical and functional response of predators to a long-term decline in mammalian prey at a semi-arid neotropical site. Oecologia 89: 90-101.

Jaksic FM, Feinsinger P, and Jiménez JE. 1993. A long-term study on the dynamics of guild structure among predatory vertebrates at a semi-arid neotropical site. Oikos 67: 87-96.

Kingsford RT, Wong PS, Braithwaite LW, and Maher MT. 1999. Waterbird abundance in eastern Australia, 1983-92. Wildlife Res 26: 351-66.

Kitzberger T, Swetnam TW, and Veblen TT. 2001. Inter-hemispheric synchrony of forest fires and the El Niño-Southern Oscillation. Global Ecol Biogeogr 10: 315-26.

Letnic M, Tamayo B, and Dickman CR. 2005. The responses of mammals to La Niña (ENSO) - associated rainfall, predation and wildfire in arid Australia. J Mammal 86: 689-703.

Letnic M, Dickman CR, Tischler M, et al. 2004. The responses of small mammals and lizards to fire and rainfall in arid Australia. $J$ Arid Environ 59: 85-114.

Lima M, Keymer JE, and Jaksic FM. 1999. ENSO-driven rainfall variability and delayed density dependence cause rodent outbreaks in western South America: linking demography and population dynamics. Am Nat 153: 476-91.

Lima M, Stenseth NC, and Jaksic FM. 2002. Population dynamics of a South American small rodent: seasonal structure interacting with climate, density-dependence and predator effects. P Roy Soc Lond B Bio 269: 2579-86.

López BC, Sabaté S, Gracia CA, and Rodríguez R. 2005. Wood anatomy of Prosopis pallida from Peru and its suitability for dendrochronology. J Arid Environ 61: 541-54.

Ludwig J, Tongway D, Freudenberger D, et al. 1997. Landscape ecology function and management: Principles from Australia's rangelands. Collingwood, Australia: CSIRO.

McPhaden MJ. 2004. Evolution of the 2002/03 El Niño. B Am Meteorol Soc 85: 677-95.

Meserve PL, Milstead WB, Gutiérrez JR, and Jaksic FM. 1999. The interplay of biotic and abiotic factors in a semiarid Chilean mammal assemblage: results of a long-term experiment. Oikos 85: 364-72.

Meserve PL, Milstead WB, and Gutiérrez JR. 2001. Results of a food addition experiment in a north-central Chile small mammal assemblage: evidence for the role of "bottom-up" factors. Oikos 94: $548-56$.

Meserve PL, Kelt DA, Milstead WB, and Gutiérrez JR. 2003. Thirteen years of shifting top-down and bottom-up control. BioScience 53: 633-46.

Page SE, Siegert F, Rieley JO, et al. 2002. The amount of carbon released from peat and forest fires in Indonesia during 1997. Nature 420: 61-65.
Polis GA, Hurd SD, Jackson CT, and Sánchez Piñero F. 1997. El Niño effects on the dynamics and control of an island ecosystem in the Gulf of California. Ecology 78: 1884-97.

Richter MA and Ise M. 2005. Monitoring plant development after El Niño 1997/98 in northwestern Peru. Erdkunde 59: 136-55.

Rietkerk M and van de Koppel J. 1997. Alternate stable states and threshold effects in semiarid grazing systems. Oikos 79: 69-76.

Sánchez Piñero F and Polis GA. 2000. Bottom-up dynamics of allochthonous input: direct and indirect effects of seabirds on islands. Ecology 81: 3117-32.

Scheffer M and Carpenter SR. 2003. Catastrophic regime shifts in ecosystems: linking theory to observation. Trends Ecol Evol 18: 648-55.

Scheffer M, Westley F, Brock WA, and Holmgren M. 2002. Dynamic interaction of societies and ecosystems: linking theories from ecology, economy and sociology. In: Gunderson LH and Holling CS (Eds). Panarchy: understanding transformations in human and natural systems. Washington, DC: Island Press.

Scheffer M, Holmgren M, Brovkin V, and Claussen M. 2005. Synergy between small and large-scale feedbacks of vegetation on the water cycle. Global Change Biol 11: 1003-12.

Schwinning S and Sala OE. 2004. Hierarchy of responses to resource pulses in arid and semi-arid ecosystems. Oecologia 141: 211-20.

Silva SI, Lazo I, Silva-Aránguiz E, et al. 1995. Numerical and functional response of burrowing owls to long-term mammal fluctuations in Chile. J Raptor Res 29: 250-55.

Skidmore AK. 1987. Predicting bushfire activity in Australia from El Niño Southern Oscillation Events. Aust Forest Res 50: 231-35.

Stapp P, Antolin MF, and Ball M. 2004. Patterns of extinction in prairie-dog metapopulations: plague outbreaks follow El Niño events. Front Ecol Environ 2: 235-40.

Stapp P and Polis GA. 2003. Influence of pulsed resources and marine subsidies on insular rodent populations. Oikos 102: 111-23.

Stapp P, Polis GA, and Sánchez Piñero F. 1999. Stable isotopes reveal strong marine and El Niño effects on island food webs. Nature 401: 467-69.

Vidiella PE, Armesto JJ, and Gutiérrez JR. 1999. Vegetation change and sequential flowering after rain in the southern Atacama Desert. J Arid Environ 43: 449-58.

Vilela P. 2002. Reforestación participativa en Piura durante el Fenómeno El Niño 1996-1997. Peru: Serie Lecciones Aprendidas No 8, INRENA - Proyecto Algarrobo.

Westerling AL, Gershunov A, Brown TJ, et al. 2003. Climate and wildfire in the western United States. BAMS May: 595-604.

Wright SJ. 2005. The influence of the El Niño Southern Oscillation on tropical forests. In: Bermingham E, Dick C, and Moritz C (Eds). Tropical rainforests: past, present and future. Chicago, IL: University of Chicago Press.

${ }^{4}$ Departamento d'Ecologia, Fac de Biologia, Universidad de Barcelona, Av Diagonal 645, 08028 Barcelona, Catalunya, Spain; ${ }^{5}$ CSIRO Sustainable Ecosystems, GPO Box 284, Canberra ACT 2601, Australia; ${ }^{6}$ Departamento de Biología, Universidad de La Serena, Casilla 599 and Centro de Estudios Avanzados en Zonas Áridas (CEAZA), La Serena, Chile; ${ }^{7}$ Department of Biology, University of New Mexico, Albuquerque, NM 87131, USA; ${ }^{8}$ Center for Advanced Studies in Ecology and Biodiversity (CASEB), Santiago, Chile; ${ }^{9}$ Department of Wildlife, Fish and Conservation Biology, University of California, Davis, Davis, CA 95616, USA; ${ }^{10}$ Parks and Wildlife Service of Northern Territory, PO Box 30, Palmerston NT, Australia 0831; ${ }^{11}$ Northern Illinois University, DeKalb, IL 60115, USA; ${ }^{12}$ National Park Service, University of Rhode Island, Kingston, RI 02881, USA; ${ }^{13}$ Department of Environmental Science and Policy, University of California, Davis, Davis, CA 95616, USA (deceased); ${ }^{14}$ Institute of Geography, FAU, Kochstr. 4/4, D 91054 Erlangen, Germany 